\title{
Efektifitas peraturan daerah tentang perlindungan anak dalam memberikan perlindungan kepada anak
}

\author{
Murjani $^{1}$, Suwardi Sagama ${ }^{2}$,
}

${ }^{1}$ Murjani; Fakultas Syariah IAIN Samarinda; Jl. H.A.M. Rifaddin, Harapan Baru, Kec. Loa Janan Ilir, Kota Samarinda; 75251; Kalimantan Timur; Indonesia.

${ }^{2}$ Suwardi Sagama; Fakultas Syariah IAIN Samarinda; Jl. H.A.M. Rifaddin, Harapan Baru, Kec. Loa Janan Ilir, Kota Samarinda; 75251; Kalimantan Timur; Indonesia.

\section{ARTICLEINFO}

Article history:

Received 2020-01-08

Received in revised form

2020-03-13

Accepted 2020-04-02

\section{Kata kunci:}

Peraturan Daerah; Penegakan Hukum; Perlindungan Anak.

\section{Keywords:}

Regional Regulations; Law Enforcement; Child Protection.

DOI: https://doi.org/10.26905/ idjch.v11i1.3437.

How to cite item:

Murjani \& Suwardi S. (2020). Efektifitas peraturan daerah tentang perlindungan anak dalam memberikan perlindungan kepada anak. Jurnal Cakrawala Hukum, 11(1), 102-110. doi:10.26905/ idjch.v11i1.3437.

\begin{abstract}
Abstrak
Undang-undang tentang perlindungan anak telah dibentuk sejak tahun 2002 dan dirubah sebanyak 2 kali pada tahun 2014 dan tahun 2016. Pemerintah daerah berdasarkan kewenangannya membentuk peraturan daerah tentang perlidungan anak seperti yang dilakukan oleh Kota Samarinda dan Kabupaten Kutai Kartanegara. Semangat peraturan daerah untuk menguatkan peraturan yang sudah dibentuk peraturan diatasnya dengan menyesuaikan kearifan lokalnya. Namun lembaga perlindungan anak, Pusat Pelayanan Terpadu Perlindungan Perempuan dan Anak (P2TP2A) Kota Samarinda dan Kabupaten Kutai kartanegara dalam penanganan kasus menggunakan undang-undang bukan peraturan daerah. P2TP2A melaporkan langsung ke unit Perlindungan Perempuan dan Anak (PPA) di kantor Polisi terdekat, sehingga subjek penegakan hukum dilakukan oleh Kepolisian berdasarkan ketentuan undang-undang bukan penegakan peraturan daerah oleh satuan polisi pamong praja. Faktornya adalah sanksi hukuman pada undang-undang lebih tinggi dibanding perda, tidak tersedia unit khusus seperti Perlindungan Perempuan dan Anak (PPA) dalam organisasi satuan polisi Pamong Praja (Satpol PP) dan personil yang belum memiliki sertifikat penanganan kasus anak.
\end{abstract}

\begin{abstract}
The law on child protection has been established since 2002 and was amended twice in 2014 and 2016. Local governments based on their authority to establish regional regulations on child protection such as that carried out by Samarinda City and Kutai Kartanegara District. The spirit of regional regulations is to strengthen the regulations that have been formed above by adjusting local wisdom. However, the child protection agency, the Center for Integrated Services for the Protection of Women and Children (P2TP2A), Samarinda City and Kutai Kartanegara Regency
\end{abstract}

Corresponding Author:

* Suwardi Sagama.

E-mail address: suwardisagama.recht@gmail.com 


\section{Jurnal Cakrawala Hukum, Volume 11 No. 1 April 2020 \\ ISSN PRINT 2356-4962 ISSN ONLINE 2598-6538}

in handling cases using laws rather than regional regulations. P2TP2A reports directly to the Women's and Child Protection Unit (PPA) at the nearest Police station, so that the subject of law enforcement is carried out by the Police based on the provisions of the law not the enforcement of local regulations by the civil service police unit. The factor is that sanctions in the law are higher than the regulations, there are no special units such as the Protection of Women and Children (PPA) in the Pamong Praja police unit (Satpol PP) and personnel who do not have certificates handling child cases.

\section{Pendahuluan}

Anak sebagai korban dari tindak kejahatan di Indonesia seperti tidak ada habisnya. Kasus terhadap anak yang menjadi korban terjadi hampir disetiap daerah, lambannya penanganan pelaku kejahatan kepada anak menjadi masalah utama. Penyebab sulitnya mengungkap tindakan kekerasan terhadap anak adalah tidak adanya keberanian pada anak untuk mengungkap pelakunya. Hal tersebut terjadi karena seringkali pelaku berasal dari orang-orang terdekat, bahkan tidak jarang pelakunya merupakan orang tua kandungnya (Huda, 2008). Anak yang semestinya dijaga dan mendapatkan perlindungan yang baik, pada kenyataannya tidak didapat bahkan masa depannya terancam menjadi suram.

Kekerasan yang diterima oleh anak mempunyai dampak perubahan secara fisik, psikologi dan sosial baik jangka pendek maupun jangka panjang (Paramastri, 2010). Selain itu, meningkatnya angka kekerasan disebabkan inkonsistensi penegakan hukum. Penegakan yang dijalankan dan dilaksanakan oleh eksekutif (Rahardjo, 2012) yaitu oleh polri dan satuan polisi pamong praja. Penegakan hukum terhadap pelaku tindakan kekerasan terhadap anak diatur secara khusus pada UU No 23 Tahun 2002 tentang Perlindungan Anak yang telah diubah dua kali dan peraturan daerah tentang perlindungan anak. Seperti yang dilakukan oleh kabupaten dan kota di Kalimantan Timur yang membentuk peraturan daerah tentang perlindungan anak.
Ketentuan tersebut dapat ditemukan dalam Perda Kota Samarinda No 10 Tahun 2013 tentang Perlindungan Anak dan Perda Kabupaten Kutai Kartanegara No 20 Tahun 2013 tentang Penyelenggaraan Perlindungan Anak. Peraturan daerah dan undang-undang bersifat regeling atinya peraturan yang bersifat umum. SF. Marbun dan Moh. Mahfud dalam Ridwan HR menyebutkan bahwa suatu peraturan bersifat umum, mengikat umum dan mengatur yang bersifat umum (HR, 2013). Perda tentang perlindungan anak di Kota Samarinda dan Kabupaten Kutai Kartanegara memiliki tujuan yang sama dengan undang-undang tentang perlindungan anak yakni memberikan perlindungan kepada anak dari segala bentuk tindakan kekerasan.

Keberadaan undang-undang dan perda tentang perlindungan anak tidak berdampak pada perlindungan hukum kepada anak. Meskipun undangundang telah dilakukan revisi sebanyak 2 kali didukung dengan perda tentang perlindungan anak, kasus kekerasan kepada anak masih terjadi. Sebagaimana terlihat pada data kekerasan anak di Pusat Pelayanan Terpadu Perlindungan Perempuandan Anak (P2TP2A) Kalimantan Timur Pada tahun 2017, tercatat 27 kasus yang menjadi korban adalah anak perempuan dan anak laki-laki. Lembaga P2TP2A Kaltim adalah lembaga perlindungan anak di bawah naungan Dinas Kependudukan, Pemberdayaan perempuan dan Perlindungan Anak (DKP3A) Provinsi kaltim. Lembaga ini menjalankan fungsinya secara represif dalam advokasi kasus kekerasan terhadap anak di kepolisian, kejaksaan 


\section{Efektifitas peraturan daerah tentang perlindungan anak dalam memberikan perlindungan kepada anak}

Murjani, Suwardi Sagama

dan pengadilan berdasarkan UU tentang perlindungan anak bukan Perda tentang perlindungan anak. Lembaga P2TP2A juga ada di kabupaten/ kota dengan fungsi yang sama. Sistem pendampingan kasus kekerasan kepada anak dilakukan secara otonomi tanpa ada instruksi atau intervensi dari tingkatan provinsi ke kabupaten/kota.

Berdasarkan latarbelakang diatas, peneliti melakukan penelitian dengan menganalisa efektifitas peraturan perundang-undangan yakni Perda tentang perlindungan anak di Kota Samarinda dan Kabupaten Kutai Kertanegara dengan judul Efektifitas Peraturan Daerah Tentang Perlindungan Anak Dalam Memberikan Perlindungan Kepada Anak.

\section{Metode}

Penelitian ini dilakukan dengan metode yuridis empiris, yaitu melakukan kajian atau analisa perilaku dan akibat yang ditimbulkan oleh perilaku manusia di tengah kelompok masyarakat komunal dan heterogen (Muhammad, 2004). Penelitian akan berinteraksi langsung dengan para penegak hukum yang memiliki kompetensi melakukan penegakan hukum dengan cara melakukan wawancara. Sebagai landasan yuridis dari penelitian ini, peneliti akan melakukan analisa secara yuridis berdasarkan peraturan perundang-undangan yang berlaku sesuai fokus terhadap penelitian yaitu berkaitan dengan peraturan daerah khususnya peraturan daerah tentang anak.

Sifat penelitian ini adalah deskripsi kualitatif. Maksudnya adalah permasalahan dalam penelitian akan diurai dengan lengkap berdasarkan teori dan praktek. Peneliti akan menjelaskan secara detail terhadap permasalahan sesuai dengan judul dan rumusan masalah yang diangkat dalam penelitian. Gambaran penelitia akan melakukan penelitian dengan mengukur kualitas dalam penelitian ini. Kemudian peneliti meyimpulkan menjadi pokok pembahasan sebagaimana rumusan masalah yang ditentukan, sehingga tali kesimpulan untuk mendapatkan sebuah jawaban dari rumusan masalah terjawab tuntas pada hasil dari tali kesimpulan.

\section{Pembahasan}

\subsection{Efektifitas peraturan daerah Kabupaten Kukar dan Kota Samarinda tentang perlindungan anak dalam memberikan perlindungan kepada anak}

Perlindungan terhadap anak yang menjadi korban tindakan kekerasan tidak dapat dihindari apalagi dibiarkan. Indonesia Sebagai negara hukum yang dideklarasikan dalam Pasal 1 ayat (3) UUD NRI Tahun 1945 sejatinya berimplikasi terhadap semua kegiatan atau aktifitas dengan berpedoman terhadap hukum positif di Indonesia. Hukum positif memiliki arti sebagai peraturan yang dibuat secara tertulis dan tidak tertulis yang berlaku saat itu dengan mengikat secara umum atau khusus (Manan, 2004). Peraturan berperan sebagai alat kontrol yang dapat mempengaruhi sosial masyarakat seperti mencegah terjadinya suatu perbuatan (Preventif) dan memberikan sanksi kepada pelaku kejahatan (Represif).

Peraturan perundang-undangan tentang perlindungan anak dibuat sebagai alat untuk membuat efek jera terhadap pelaku. Dalam Impelementasinya, alih-alih menghadirkan efek jera, justru kekerasan kepada anak terus terjadi, dengan pelaku dan motif yang baru. Pelaku kekerasan bukan lagi dari orang jauh melainkan oleh orang yang dekat dengan anak. Kejadian masa lalu menjadi dasar utama orang terdekat dengan anak melakukan kekerasan (Tuliah, 2018). Atas dasar itu Pemerintah bersama DPR RI melakukan revisi Undang-undang tentang perlindungan anak dengan meningkatkan sanksi hukuman, sebelumnya dalam undang-undang Nomor 23 tahun 2002 dan undang-undang perubahan nomor 35 tahun 2014 tentang perlindungan anak sanksi hukuman hanya penjara dan denda. Pada per- 


\section{Jurnal Cakrawala Hukum, Volume 11 No. 1 April 2020}

ISSN PRINT 2356-4962 ISSN ONLINE 2598-6538

ubahan kedua undang-undang tentang perlindungan anak nomor 17 tahun 2016 memasukan sanksi hukuman kebiri melalui suntik elektronik.

Di tingkat daerah, upaya untuk menguatkan penegakan hukum kepada pelaku kejahatan seksual, pemerintah daerah bersama DPRD melakukan pembentukan peraturan daerah tentang perlindungan anak. Keberadaan peraturan daerah tentang perlindungan anak diharapkan dapat memberikan rasa aman kepada anak secara khusus di daerah karena kasus kekerasan terhadap anak menjadi ancaman serius terhadap tumbuh kembang anak, tidak hanya mengancam anak-anak namun juga kepada orang tua. Perlindungan ini dilakukan oleh Pemerintah daerah dengan memberikan pelayanan kepada korban ketika terbukti anak mendapat perlakuan tindakan kekerasan (Dewi, 2015).

Anak yang menjadi korban dari tindakan kejahatan sudah tentu akan mendapatkan dampak negatif secara psikologi. Anak akan takut untuk bermain, takut untuk beraktifitas, malas untuk belajar dan cenderung menjadi pemdiam. Bahkan anak berpotensi menjadi pelaku dari kekerasan yang pernah dialami atau menjadi korban dari kekerasan tersebut. Sedangkan orang tua turut menjadi korban, dimana ketika anaknya menjadi korban maka rangkaian kegiatan atau aktifitas akan teralihkan kepada pemulihan anak sehingga tidak fokus dalam menyelesaikan masalah yang dihadapi. Untuk menjaga konsistensi berlakunya hukum dengan baik, maka diperlukan sinergi antara pembentuk peraturan dengan pelaksana dari peraturan sehingga terjadi konsistensi penegakan hukum didalam dan diluar pengadilan (Sagama, 2016).

Sebagaimana fungsi dari undang-undang, keberadaan peraturan daerah diharapkan menjadi alat untuk membuat efek jera terhadap pelaku pelanggaran. Akan tetapi perda tidak memberikan dampak pada perlindungan kepada anak karena tidak memiliki kekuatan dalam memberikan perlindungan kepada anak. Suatu peraturan dapat menjadi efek jera apabila dalam pembuatan dilakukan dengan baik dan benar mulai dari rumusan, tujuan hingga sanksi hukuman untuk yang melanggar dalam peraturan tersebut (Sakman, 2016). Sebagaimana Perda Kota Samarinda No 10 Tahun 2013 tentang Perlindungan Anak. Keberadaan Perda tentang perlindungan anak tidak digunakan oleh lembaga perlindungan anak P2TP2A Kota Samarinda dalam melakukan advokasi dan pendampingan hukum pada kasus kekerasan terhadap anak. Hasil wawancara dengan ketua P2TP2A Kota Samarinda mengatakan bahwa kasus kekerasan kepada anak yang ditangani tidak menggunakan Perda Kota Samarinda Nomor 10 Tahun 2013 tentang Perlindungan Anak melainkan UU tentang perlindungan anak.

Jumlah kasus kekerasan terhadap anak di Kota Samarinda pada tahun 2016 berjumlah 345 kasus (Dinas Pemberdayaan Anak dan Perempuan Kota Samarinda, 2016). Kasus-kasus tersebut ditangani oleh tim advokasi dan hukum dengan melaporkan di Polresta Samarinda dan Polsekpolsek yang ada di samarinda. Kondisi yang sama juga dilakukan P2TP2A Kabupaten Kutai Kartanegara yang melaporkan kasus kekerasan kepada anak di kepolisian tempat dimana perkara terjadi baik Polres maupun Polsek di Kutai Kertanegara. Pilihan untuk melaporkan kasus kekerasan kepada anak tidak lepas dari jenis pidana perda yakni pelanggaran sedangkan kasus kekerasan kepada anak adalah kejahatan. Berdasarkan hasil wawancara dengan Kepala Satuan polisi pamong praja (Kasatpol) Kota Samarinda, bahwa satuan polisi pamong praja Kota Samarinda lebih banyak menangani kasus penertiban anak jalanan berdasarkan perda tentang anak jalanan, bukan penegakan hukum terhadap tindak kekerasan terhadap anak yang berdasarkan perda tentang perlindungan anak (Sagama, 2016).

Penanganan Kasus kekerasan terhadap anak lebih diutamakan dalam penegakan hukumnya kepada Polri dengan menjalankan Undang-undang 


\section{Efektifitas peraturan daerah tentang perlindungan anak dalam memberikan perlindungan kepada anak}

Murjani, Suwardi Sagama

tentang perlindungan anak. Selaras dengan pertanyaan diatas, hasil wawancara bersama kabid dan kasi penegakan hukum Satpol PP Kabupaten Kutai Kartanegara mengatakan hingga saat ini Satpol PP belum pernah menegakkan peraturan daerah tentang perlindungan anak, dengan alasan peraturan daerah di Kabupaten Kutai Kartanegara yang mengatur tentang perlindungan anak belum juga diharmonisasikan. Oleh karenanya evaluasi dapat dilakukan karena kondisi masyarakat terus berkembang dengan melakukan kajian termasuk harmonisasi peraturan perundang-undangan untuk kepentingan terbaik buat anak.

Hirearki peraturan perundang-undangan, Perda tidak boleh bertentangan dengan peraturan diatasnya termasuk dengan undang-undang. Terdapat beberapa pertentangan yang perlu di perhatikan untuk revisi. Pertama, muatan materi pasal dan ayat dalam peraturan da erah tentang perlindungan anak memiliki kesamaan dengan undang-undang tentang perlindungan anak. Pada Perda Kota Samarinda No 10 Tahun 2013 tentang Perlindungan anak, pada Pasal 4 huruf a menyebutkan setiap anak berhak untuk dapat hidup, tumbuh, berkembang dan berpartisipasi secara wajar sesuai usianya, harkat dan martabat kemanusiaan, serta mendapat perlindungan dari tindak kekerasan, eksploitasi dan keterlantaran. Hak sebagaimana yang diatur dalam perda ini diatur juga dalam UU No 23 Tahun 2002 tentang Perlindungan Anak dan UU No 35 Tahhun 2014 tentang Perubahan atas UU No 23 Tahun 2002 tentang Perlindungan Anak. Pada Pasal 9 ayat (1a) disebutkan: Setiap Anak berhak mendapatkan perlindungan di satuan pendidikan dari kejahatan seksual dan Kekerasan yang dilakukan oleh pendidik, tenaga kependidikan, sesama peserta didik, dan/atau pihak lain.

Kedua, Pada ketentuan hukum yang mengatur sanksi dalam Perda Kota Samarinda Nomor 10 Tahun 2013 tentang Perlindungan Anak dan Perda Kabupaten Kutai Kertanegara Nomor 20
Tahun 2013 tentang Penyelenggaraan Perlindungan Anak mengatur pidana kurungan paling lama 6 bulan dan denda paling banyak Rp.50.000.000; secara nyata tidak sejalan dengan perlindungan terhadap anak dimana keinginan kuat untuk memberikan perlindungan hukum terhadap anak dengan semaksimal mungkin tidak terwujud. Hal ini dilandasi atas dasar sanksi hukuman dalam undang-undang yang terus ditingkatkan berdasarkan perbuatan yang dilakukan, sebagaimana pada undang-undang Nomor 17 Tahun 2016 tentang Perubahan kedua undang-undang nomor 23 tahun 2002 yang mengatur ketentuan sanksi dan jenis pidana terhadap pelaku kejahatan anak sebagaimana pada Pasal 81 yakni hukuman maksimal yang diberikan selama 20 tahun dan ditambah hukuman berupa kebiri dan suntik elektronik bahkan pelaku akan diumumkan apabila memenuhi ketentuan dalam undang-undang tersebut.

Ketiga, kategori tindak pidana berupa pelanggaran hanya memberikan kelonggaran terhadap pelaku kejahatan terhadap anak karena kategori pelanggaran terhadap jenis hukuman yakni bukan dipenjara namun dikurung. Penyebutan penjara dan dikurung berkonsekuensi pada keseriusan dalam melakukan penegakan hukum terhadap pelaku kekerasan anak. Eddy O.S. Hiariej dalam Bukunya Prinsip-prinsip hukum pidana mengatakan:

"Pembagian perbuatan pidana ke dalam kejahatan dan pelanggaran membawa beberapa konsekuensi. Pertama, Tindakan dan akibat yang ditimbulkan kejahatan lebih berbahaya bila dibandingkan dengan pelanggaran. Kedua, konsekuensi dari yang pertama, sangat berpengaruh pada sanksi pidana yang diancamkan. Kejahatan diancam dengan pidana yang lebih berat bila dibandingkan dengan pelanggaran. Ketiga, percobaan melakukan suatu kejahatan, maksimum ancaman pidananya dikurangi sepertiga, sedangkan percobaan melakukan pelanggaran tidak dincam pidana (Hiraiej, 2016). 


\section{Jurnal Cakrawala Hukum, Volume 11 No. 1 April 2020}

ISSN PRINT 2356-4962 ISSN ONLINE 2598-6538

Upaya maksimal harus dilakukan dengan mengutamakan kepentingan anak sebagai pemegang tongkat estafet sebelum generasi penerus akan menjadi punah.

\subsection{Faktor penghambat dalam penerapan perda tentang perlindungan anak}

Adanya peraturan dapat menjamin kepastian hukum serta dapat memberikan nilai-nilai keadilan kepada masyarakat. Selain itu, peraturan juga dapat memberikan nilai manfaat yang baik kepada masyarakat. Peraturan bekerja secara represif dan prventiv. Berfungsi sebagai represif karena memberikan sanksi hukum kepada pelaku kejahatan/ pelanggaran. Sedangkan berfungsi sebagai preventif karena menjadi warning atau peringatan kepada setiap orang bahwa tindakan kekerasan terhadap anak akan diberikan hukuman. Tujuan lain dari peraturan sebagaimana yang dikatakan oleh Roscoe Pound bahwa peraturan berfungsi sebagai alat perekayasa sosial. Peraturan akan mempengaruhi ruang kehidupan masyarakat mulai dari lapisan bahwa hingga pada lapisan atas. Setiap aktifitas yang dilakukan oleh masyarakat baik secara individual maupun kelompok harus berdasarkan peraturan yang berlaku.

Sebagaimana pada peraturan daerah tentang perlindungan anak yang dimiliki Kota Samarinda dan Kabupaten Kutai Kertanegara. Peraturan daerah yang dibentuk dengan tujuan untuk memberikan perlindungan kepada anak mulai anakanak berusia 0 bulan hingga sebelum berusia 18 tahun. Senyatanya peraturan daerah ini ada, tapi tidak digunakan oleh lembaga perlindungan anak dalam melakukan pendampingan anak. Lembaga perlindungan anak P2TP2A lebih memilih melapor kasus yang didampingi ke kantor polisi berdasarkan kewenangan yang diatur oleh undangundang bukan satpol PP yang melakukan penegakan terhadap perda. Kealpaan dalam menggunakan perda perlindungan anak bukan tanpa alasan, tentunya setiap pilihan yang dipilih memiliki pertimbangan tertentu. Berikut alasan yang digunakan dengan menganalisa berdasarkan teori dan praktek.

\section{a) Penegakan hukum peraturan daerah}

Kewenangan Satpol PP dalam penegakan Perda diatur dalam Pasal 4 Peraturan Pemerintah Nomor 6 Tahun 2010 tentang Satuan Polisi Pamong Praja. Satpol PP mempunyai tugas dalam penegakan Perda dan penyelenggaraan ketertiban umum dan ketenteraman masyarakat. Dasar tersebut yang dijadikan satpol PP Kota Samarinda dan Kabupaten Kutai Kertanegara dalam penegakan perda. Hasil wawancara dengan satpol PP Kota Samarinda mengatakan satpol PP belum pernah melakukan penegakan hukum kepada pelaku kekerasan kepada anak berdasarkan Perda Kota Samarinda No 10 tahun 2013 tentang Perlindungan Anak.

Lembaga perlindungan anak dan masyarakat, ketika mengetahui adanya suatu kasus kekerasan terhadap anak yang terjadi di lingkungan sekitarnya langsung melaporkan di kantor polisi terdekat. Mereka mengetahui bahwa setiap kasus hukum pidana dilaporkan ke polisi untuk di proses mulai penyidikan, penuntutan di kejaksaan dan pemidanaan di pengadilan. Selain itu, sanksi hukum bagi pelaku kekerasan terhadap anak dalam undang-undang memiliki perbedaan yang mencolok, sehingga jika diterapkan dapat menyebabkan ketidakadilan untuk korban.

Sebagaimana dalam Pasal 76D UU Nomor 35 Tahun 2014 tentang Perlindungan Anak bawah pelaku kejahatan seksual pidana penjara paling singkat 5 (lima) tahun dan paling lama 15 (lima belas) tahun dan denda paling banyak Rp 5.000. 000.000,00 (lima miliar rupiah). Sedangkan pada perda Kota Samarinda Nomor 10 Tahun 2013 tentang Perlindungan Anak yaitu Ketentuan pidana sebagaimana dimaksud pada ayat (1) huruf b dan huruf c berupa ancaman pidana kurungan paling 
lama 6 (enam) bulan atau pidana denda paling banyak Rp 50.000.000,00 (Lima Puluh Juta Rupiah). Menurut Hans Kelsen dalam A. Rosyid Al Atok menyebutkan bahwa hukum mengatur pembentukannya sendiri karena norma hukum yang satu menentukan cara untuk membuat norma hukum lainnya, dan sampai derajat tertentu juga menentukan isi norma lainnya tersebut (Atok, 2015). Oleh karenanya dalam impelementasi suatu peraturan dapat memperhatikan substansi dari materi peraturan dan objek yang diatur.

\section{b) Unit khusus anak dan pelatihan personil Satpol PP}

Unit khusus yang dimaksud adalah bidang yang secara spesifik melakukan penanganan terhadap suatu kasus dengan personil yang telah diberikan atau diikutkan pelatihan secara khusus untuk menangani kasus tersebut. Dalam hal ini penanganan kasus anak tidak dapat dilakukan dengan asal-asalan tanpa terlebih dahulu diberikan pembekalan atau pelatihan. Harus ada sub organisasi yang khusus melakukan penanganan kasus kekerasan kepada anak. Di Kepolisian memiliki bidang khusus untuk penanganan kasus anak yaitu unit perlindungan perempuan dan anak (PPA). Tujuannya agar kasus anak yang dilaporkan dan pembuatan beritaacara pemeriksaan (BAP) dapat mendukung kerahasiaan data korban.

Berdasarkan hasil penelitian yang dilakukan, di satpol PP baik di Kota Samarinda maupun Kabupaten Kutai Kertanegara tidak terdapat unit khusus yang membidangi tentang perlindungan anak. Ketika terjadi pelanggaran terhadap perda maka yang akan melakukan penanganan adalah bidang penegakan perundang-undangan daerah atau bidang penegakan produk hukum daerah. Hal ini semakin menegaskan bahwa ketiadaan unit khusus atau sub organisasi dalam penanganan kasus tentang perlindungan anak akan berdampak terhadap pada tumbuh kembang anak.
Selain itu personil atau individu yang dimiliki oleh satpol pp Kota Samarinda sebanyak 6 orang dan Satpol PP Kabupaten Kutai Kertanegara sebanyak 3 orang hanya memiliki kualifikasi dalam penanganan kasus secara umum bukan spesifik kepada kasus tertentu. Kualifikasi umum tentu dalam penegakan perda pada kasus perlindungan anak akan berbeda ketika menangani penegakan perda secara umum, Keberadaan Personil Satpol PP yang dimiliki mempengaruhi dalam melakukan penegakan, penuntutan dan hakim yang melakukan persidangan juga menjadi satu kesatuan dengan unit khusus tersebut. Dengan keahlian yang dimiliki personil akan terlihat dalam penanganan baik kasus secara umum maupun secara khusus dimana memiliki letak perbedaan. Dalam penanganan kasus secara khusus personil yang memeriksa harus memiliki pemahaman tentang anak, karena yang diutamakan adalah perkembangan dan tumbuh kembang anak. Pada UU tentang sistem peradilan pidana anak pengganti dari UU tentang pengadilan anak mengatur persidangan khusus untuk anak.

Berdasarkan Pasal 5 UU Nomor 11 Tahun 2012 tentang SPPA disebutkan sistem peradilan pidana anak wajib mengutamakan keadilan restoratif maksudnya adalah penyelesaian perkara tindak pidana dengan melibatkan pelaku, korban, keluarga pelaku/korban, dan pihak lain yang terkait untuk bersama-sama mencari penyelesaian yang adil dengan menekankan pemulihan kembali pada keadaan semula, dan bukan pembalasan. Dalam undang-undang ini juga diatur kriteria penunut umum seperti yang diatur pada Pasal 41 bahwa seorang jaksa dalam penanganan kasus anak wajib memiliki keahlian atau sertifkat tentang penanganan anak. Oleh karenanya dalam penegakan perda, satpol PP harus memiliki unit khusus dan personil memiliki keahlian/sertifikasi untuk kepentingan anak. 


\section{Jurnal Cakrawala Hukum, Volume 11 No. 1 April 2020}

ISSN PRINT 2356-4962 ISSN ONLINE 2598-6538

\section{c) Sanksi hukuman dalam peraturan daerah}

Sanksi adalah hukuman yang diberikan kepada seseorang setelah melakukan suatu kesalahan baik pelanggaran maupun tindak kejahatan. Sanksi menjadi suatu keniscahyaan kepada pelaku atas perbuatan yang dilakukan. Dalam peraturan perundang-undangan di Indonesia terdapat 3 jenis sanksi yang pada umumnya terjadi dan berhubungan langsung dengan masyarakat yakni, sanksi administrasi, sanksi perdata dan sanksi pidana. Jenis sanksi ini memiliki ruang lingkup yang berbeda, sanksi administrasi berhubungan langsung dengan antara orang dan/atau badan hukum dengan pemerintah. Sanksi perdata terkait ganti rugi antara subjek hukum berdasarkan objek hukum yang disepakati.

Jenis sanksi terakhir adalah sanksi pidana yang berhubungan masyarakat seara personal atau kelompok dengan negara yang diwakilkan oleh jaksa atau penuntut umum. Jenis sanksi pidana pada peraturan bersifat regeling yaitu KUHAP dan Perda. Perbedaan jenis sanksi dan denda peraturan bersifat regeling ini dapat ditemukan dalam UU No 12 Tahun 2011 tentang Pembentukan Peraturan Perundang-undangan. Pada Pasal 15 ayat (1) disebutkan materi muatan mengenai ketentuan pidana hanya dapat dimuat dalam: a.Undang-undang; b.peraturan daerah provinsi; c.Peraturan daerah kabupaten/kota.

Pasal 15 ayat (2) kembali dijelaskan tentang ketentuan pidana sebagaimana dimaksud pada ayat (1) huruf $b$ dan huruf $c$ berupa ancaman pidana kurungan paling lama 6 (enam) bulan atau pidana denda paling banyak Rp.50.000.000,00 (lima puluh juta rupiah). Pada ayat (3) disebutkan peraturan daerah Provinsi dan peraturan daerah kabupaten/ kota dapat memuat ancaman pidana kurungan atau pidana denda selain sebagaimana dimaksud pada ayat (2) sesuai dengan yang diatur dalam peraturan perundang-undangan lainnya. Sanksi hukuman sebagaimana yang dimaksud diatas menegaskan bahwa sanksi pidana dan denda pada perda cukup ringan.

\section{Simpulan}

Tindakan kekerasan terhadap anak adalah sebuah kejahatan yang dalam penegakan hukumnya dapat mengutamakan efek jera. Tindakan kekerasan terhadap anak yang terjadi di Kota Samarinda dan Kabupaten Kutai Kartanegara dengan data yang dihimpun dari DP2A Kota Samarinda pada tahun 2016 terdapat sejumlah 345 kasus anak dan dari DP2A Kabupaten Kutai Kartanegera pada tahun 2017 sejumlah 133 kasus anak. Jumlah Kasus tersebut informasi atau laporan kasus yang diterima P2TP2A Kota Samarinda dan P2TP2A Kabupaten Kukar langsung dilaporkan ke Unit PPA Polres atau PPA Polsek tempat terjadinya suatu perkara bukan ke satpol PP Artinya penanganan kasus menggunakan undang-undang tentang perlindungan anak bukan menggunakan perda tentang perlindungan anak. Keberadaan perda dalam memberikan perlindungan kepada anak dapat dilihat dalam penanganan yang dilakukan oleh lembaga aktif P2TP2A dalam faktor yang penghambat yakni: Penegakan Hukum Peraturan Daerah, Unit Khusus Anak dan Pelatihan Personil Satpol PP, dan Sanksi Hukum Dalam Peraturan Daerah.

\section{Daftar pustaka}

Al Atok, A. Rosyid. 2015. Konsep Pembentukan Peraturan Perundang-undangan. Malang. Setara Press.

Anggoro, S. (2019). Politik Hukum: Mencari Sejumlah Penjelasan. Jurnal Cakrawala Hukum, 10(1), 77-86. doi:10.26905/idjch.v10i1.2871.

Dewi, Ari Atu. \& Anak Agung Istr. Dasar Kewenangan Pemerintah Daerah Kabupaten Badung Dalam Memberikan Standar Pelayanan Bagi Perempuan dan Anak Korban Kekerasan. Udayana Master Law Journal. Vol. 4 2015, no, 3: 610-622 hlm 618.

Hamidi, Azim, Paradigma Baru Pembentukan dan Analisis Peraturan Daerah (Studi Atas Perda Pelayanan Publik dan Perda Keterbukaan Informasi Publik. Jurnal Hukum No. 3 Vol. 18 Juli 2011: $336-363$. 


\section{Efektifitas peraturan daerah tentang perlindungan anak dalam memberikan perlindungan kepada anak}

Murjani, Suwardi Sagama

Hiariej, Eddy O.S. 2016. Prinsip-Prinsip Hukum Pidana. Yogyakarta. Cahaya Atma Pustaka.

HR, Ridwan. 2013. Hukum Administrasi Negara. Jakarta. Rajawali Pers.

Huda, Nurul. KekerasanTerhadapAnak dan Masalah Sosial yang Kronis. PenaJustisia. Volume VII No. 14, tahun 2008.

Manan, Bagir. 2004. Hukum Positif Indonesia. Yogyakarta. FH UII Press.

Mertokusumo, Sudikno. 2008. Mengenal Hukum, Yogyakarta, Liberty.

Mertokusumo, Sudikno. 2012. Teori Hukum. Yogyakarta. Cahaya Atma Pustaka.

Muhammad, Abdulkadir. 2004. Hukum dan Penelitian Hukum. Bandung. Citra Aditya Bakti.

Muhammad. Aspek Perlindungan Anak Tindak Kekerasan (Bullying) Terhadap Siswa Korban Kekerasan di Sekolah (Studi Kasus di SMK Kabupaten Banyumas). Jurnal Dinamika Hukum. Vol. 9 No. 32009.

Paramastri, Ira., dkk. Early Prevention Toward Sexial Abuse on Children. Jurnal Psikologi. Volume 37, No. 1, Juni 2010: 1 - 12.

Raharjo, Sartjipto. 2012. Ilmu Hukum. Bandung. Citra Aditya Bakti.

Rahayu, D. (2019). Pembangunan Hukum Sebagai Upaya Peningkatan Daya Saing Daerah. Jurnal Cakrawala Hukum, 10(1), 1-8. doi:10.26905/idjch.v10i1.3181

Sagama, Suwardi. AnalisisKonsepKeadilan, Kepastian Hukum dan Kemanfaatan dalam Pengelolaan Lingkungan. Mazahib Jurnal Pemikiran Hukum Islam Vol XV, No. 1 Juni 201620 - 41. DOI: http:// dx.doi.org/10.21093/mj.v15i1.590.

Sagama, Suwardi. Tinjauan Yuridis Terhadap Hak Pengasuhan Anak yang Tinggal Di Rumah Tahanan. Jurnal Kertha Patrika. Volume 38, No. 3 2016: 227 - 238.
Sakman. Studi Tentang Anak Jalanan (Tinjauan Implementasi Perda Kota Makasar Nomor 2 Tahun 2008 tentang Pembinaan Anak Jalanan, Gelandangan, Pengemis, dan Pengamen di Kota Makasar). Volume XI Nomor 2, Oktober 2016.

Tuliah, Sabda. Kajian Motif Pelaku Kekerasan Seksual Terhadap Anak Melalui Modus Operandi Di Lingkungan Keluarga. Ejournal Sosiati-Sosiologi. 2018, 6 (2): 1-17.

Undang-Undang Negara Republik Indonesia Tahun 1945.

Undang-Undang Nomor 11 Tahun 2012 tentang Sistem Peradilan Pidana Anak (Lembaran Negara Republik Indonesia Tahun 2012 Nomor 153, Tambahan Lembaran Negara Republik Indonesia Nomor 5332).

Undang-Undang Nomor 12 Tahun 2011 tentang Pembentukan Peraturan Perundang-Undangan (Lembaran Negara Republik Indonesia Tahun 2011 Nomor 82, Tambahan Lembaran Negara Republik Indonesia Nomor 5234).

Undang-Undang Nomor 17 Tahun 2016 tentang Perubahan Ketiga Undang-Undang Nomor 23 Tahun 2002 tentang Perlindungan Anak (Lembaran Negara Republik Indonesia Tahun 2016 Nomor 237, Tambahan Lembaran Negara Republik Indonesia Nomor 5946).

Undang-Undang Nomor 23 Tahun 2002 tentang Peradilan Anak (Lembaran Negara Republik Indonesia Tahun 2002 Nomor 109, Tambahan Lembaran Negara Republik Indonesia Nomor 4235).

Undang-Undang Nomor 35 Tahun 2014 tentang Perubahan Kedua Undang-Undang Nomor 23 Tahun 2002 tentang Perlindungan Anak (Lembaran Negara Republik Indonesia Tahun 2014 Nomor 297, Tambahan Lembaran Negara Republik Indonesia Nomor 5606). 